\title{
Impact of massage on goats on the human-animal relationship and parameters linked to physiological response
}

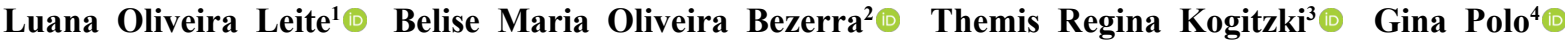 Vicente José de Figueirêdo Freitas ${ }^{1} \odot$ Maria José Hötzel ${ }^{5} \odot$ Diana Célia Sousa Nunes-Pinheiro ${ }^{1} \odot$}

${ }^{1}$ Programa de Pós-graduação em Ciências Veterinárias, Universidade Estadual do Ceará (UECE), 60714-903, Fortaleza, CE, Brasil. E-mail: luanaoliv.vet@gmail.com. Corresponding author.

${ }^{2}$ Curso de Medicina Veterinária, Universidade de Fortaleza (UNIFOR), Fortaleza, CE, Brasil.

${ }^{3}$ Instrutora de Massagem Canina na AnimaTherapy, São Paulo, SP, Brasil.

${ }^{4}$ Análise Estatística e Consultoria de Pesquisa, Bogotá, Colômbia.

${ }^{5}$ Laboratório de Etologia Aplicada e Bem-estar Animal, Universidade Federal de Santa Catarina (UFSC), Florianópolis, SC, Brasil.

ABSTRACT: Considering the benefits that massage can promote, this research aimed to apply the stroking massage in five adult goats (G1G5) assessed in group and individually for ten days. Parameters related to massage, immune system, physiology and behavior of goats were observed. There was only significant difference $(P<0.05)$ regarding behavior expressed in the presence of the masseur in $G 4$ and $G 5$, between week 1 and 2. Most goats accepted massage, except G2, with greater demonstrations of positive than negative behavior towards the masseur. Therefore, stroking massage promoted positive interactions between the masseur and goats, and should be explored as an alternative method to those existing in improving the relationship between humans and farm animals.

Key words: animal welfare, goat behavior, serum MDA, stroking massage, touch.

Impacto da massagem em cabras na relação homem-animal

e parâmetros relacionados à resposta fisiológica

RESUMO: Considerando os beneficios que a massagem pode promover, este trabalho teve como objetivo aplicar a massagem do tipo stroking em cinco cabras adultas (G1-G5) avaliadas em grupo e individualmente por dez dias. Parâmetros relacionados à massagem, sistema imunológico, fisiologia e comportamento das cabras foram observados. Houve apenas diferença significativa (P<0,05) em relação ao comportamento expresso na presença da massagista em $G 4$ e G5, entre as semanas 1 e 2. A maioria das cabras aceitou a massagem, exceto G2, com maiores demonstrações de comportamentos positivos do que negativos direcionados à massagista. Portanto, a massagem do tipo stroking promoveu interações positivas entre a massagista e as cabras, devendo ser explorada como um método alternativo aos existentes na melhora da relação entre seres humanos e animais de produção.

Palavras-chave: bem-estar animal, comportamento de cabras, MDA sérico, massagem do tipo stroking, toque.

\section{INTRODUCTION}

Human-Animal Relationship (HAR) is defined as the level of mutual perception between animals and humans through an inter-relation of proximity or distance expressed by both (ZULKIFLI, 2013). In livestock animals, aversive management of domestic ruminants can have serious consequences on productivity, reproduction and animal welfare (WAIBLINGER et al., 2006). Feeling of fear contributes to overall stress, which at high levels can become a harmful agent to the body.
In order to maintain homeostasis, animals respond to stress through the interaction of several biological defenses that can be used as indicators of animal welfare. Parameters related to the behavior can be evaluated by the latency or avoidance distance tests (BLOKHUIS et al., 2010) and physiological measures can be analyzed by immunological markers and oxidative stress of cells (CELI et al., 2017). In addition, reduction of fear of humans and improvement of HAR at farm level can be achieved using strategies such as gentle physical contact (WAIBLINGER et al., 2006). This interaction could be done through massage. 
Massage is defined as the therapeutic manipulation of soft tissues and muscles, promoting action at a mechanical level due to the mobilization of skin and tissues; at physiological, by pain control and release of endorphins and psychological through reduction of anxiety and increased relaxation (SHARP, 2012). In dogs and cats, massage is usually applied as complementary treatment of edema, osteoarthritis and chronic pain (CORTI, 2014).

However, massage also has the potential to improve the relationship between humans and animals. In dogs, the massage performed by tutors allows a better knowledge of their health (ROBERTSON \& MEAD, 2013), possibly making the human being more aware of the physical, mental and behavioral needs of their animals. In addition, positive emotions such as love, affection, and sense of security can also be transmitted by touch (FIELD, 2004).

Among the techniques, stroking is an important one because aims primarily to relax the animal, allows evaluation of tissues, decreases anxiety in pets (CORTI, 2014) and can be applied for a limited time, daily and at any time of day (SUTTON \& WHITLOCK, 2013).

Considering the benefits that massage can promote, the stroking technique was applied in the management of goats aiming to promote animal welfare, focusing on improving HAR and on the maintenance of a balanced immune system, which is central for the proper functioning of the body (MARQUES et al., 2016). Therefore, the aim of this pilot study was to test a massage protocol using the stroking technique to evaluate 1. parameters related to the immune system and physiological stress of goats before and after massage application; 2. the behavioral response of the goats to the attempts and application of massage; 3 . the period of time in which they accept the massage and 4. latency of goat to approach the masseur before and after massage application.

\section{MATERIALS AND METHODS}

\section{Housing, animals and feeding}

This study was conducted at Laboratory of Physiology and Control of Reproduction (LFCR) in State University of Ceará (UECE), located in 3047'13.992"S latitude, 38 33'14.256"W at an altitude of $30 \mathrm{~m}$, on March 2019. The temperature ranged between $24-31{ }^{\circ} \mathrm{C}$.

Five female mixed breed goats were used. Animals were housed in two slatted floor pens (P1 and $\mathrm{P} 2 ; 3 \mathrm{~m} \mathrm{x} 3 \mathrm{~m}$ ). The $\mathrm{P} 1$ goats are composed by three animals (goat 1- G1; goat 2 - G2 and goat 3 - G3) and P2 goats by two (goat 4 - G4 and goat 5 G5). The animals were kept on pasture in the morning ( 8 to $11 \mathrm{am}$ ), and the rest of time in pens, where they received chopped grass/hay with concentrate at 1:30 $\mathrm{pm}$ and chopped grass/hay at 4:00 pm.

\section{Experimental setup}

This study was conducted over a period of fifteen days (D0-D14) as demonstrated on figure 1. One female masseur applied the massage to all goats. She wore green clothes during the massage time. Stroking massage was applied using bare hands. This technique consisted of hands touching the animal in the neck-tail-limbs direction with gentle but firm pressure (SUTTON \& WHITLOCK, 2013; CORTI, 2014). However, considering results of a previous study in horses(MCBRIDE et al., 2004), massage was mainly applied in neck, shoulder and rump regions. The massage was considered fully applied after three direct minutes of hand-skin contact. The massage protocol was applied in group (Group massage - GM) and individually (Individual massage - IM) during two weeks for ten days (D3-D14). The GM protocol intended to observe behaviors of goats when they are with their pen mates (P1 and P2) during the attempts of masseur to apply the stroking massage during the morning (6 to $7 \mathrm{am}$ ).

The following steps were performed in GM: 1. the goats were led to an experimental pen; 2.the masseur entered, sat on the center of the pen and waited for interactions.; 3 after the goats initiated some contact with the masseur, attempts to touch and perform the stroking massage were made. Total time spent daily with each groupin GM was 20 minutes.

The IM protocol was applied on the afternoon (1 to $4 \mathrm{pm}$ ). The following steps were performed in IM: 1. each goat was individually conducted to an experimental pen; 2. The masseur entered and sat in the center of the pen; 3. During the first 10 minutes, the masseur waited for the goat to contact her before she made attempts to touch and massage the goat; 4 . after 10 minutes, if the goat did not interact, the masseur slowly moved towards the goatin an attempt to touch it. Three attempts were made. If the animal accepted the touch in one of these attempts, a fourth attempt was performed. If the animal did not accept the touch, the masseur returned to the center of the pen. An interval of approximately two minutes was used between each touch/massage attempt. At the touch permission, attempts to perform the massage were made. If the goat interacted with the masseur on its own initiative, an extra touch/ 


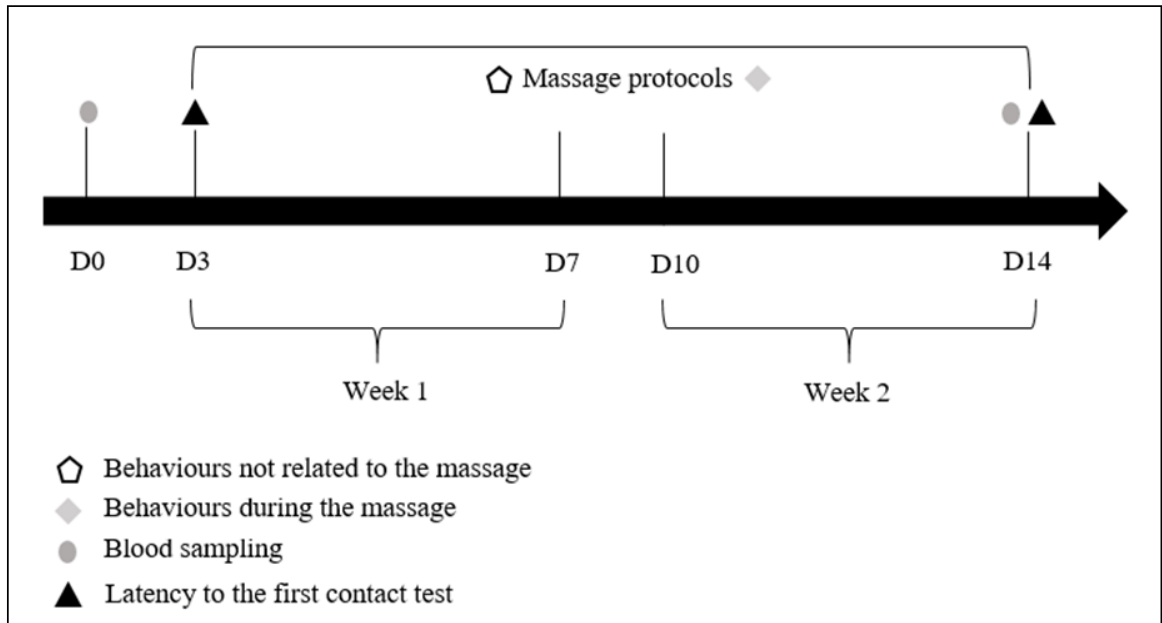

Figure 1 - Scheme of experimental goat massage protocols.

massage attempt was performed. The total time spent daily with each goat in IM was 30 minutes. Because animals were fed during the massage period, the time (before, during or after) and type of food (feed or concentrate) were also evaluated. All massage sessions were recorded.

\section{Assessment of the goats' reactions to massage}

A Sony HDR-CX130 camera positioned at a height of $1.94 \mathrm{~m}$ was used to monitor how goats reacts to the attempts and application of the massage protocols. After the beginning of massage, an adapted score (LÜRZEL et al., 2016) was given daily for each animal (Table 1).

In addition, during massage, positive (gently nibbles the masseur, sniffs, licks, leans for massage, rubs against the masseur, appears drowsy, with head tilt, etc), negative (heads-up, explicit displacement, strong bites, escape attempts, scratch, etc) and neutral behaviors (vocalizations, sniffs the floor or some structure of the pen, etc) were evaluated for each animal, adapted from MCBRIDE et al.(2004).

\section{Assessment of other behaviors during massage}

Goat's behaviors not related to the massage were also observed during protocols (Table 2). The focal-animal sampling technique was performed (ALTMANN, 1974). The behavior of the goats was evaluated by week (days 1 to 5 - W1; days 6 to 10 - W2), by P1 and P2 goats and by adding up the individual behaviors of the three goats in pen 1 (B1) and the two goats in pen 2 (B2).

During the protocols, some behaviors could not be observed due to the positioning of the camera located outside the pen. Therefore, animals presented a visible period (time in) and a non-visible period (time out) (ALTMANN, 1974), in which in GM, if one goat's body was not visible, the behaviors of the rest of the group was not accounted for; during

Table 1 - Behavior score for reaction to stroking massage in goats in Ceará, Brazil.

\begin{tabular}{lc}
\hline Score & \\
\hline 1 & Does not accept the massage $(\leq 10 \mathrm{~s} ;$ high movement and attempt to escape $)$ \\
2 & Accepts the massage less than half the time $(>10 \mathrm{~s}$ and $<1: 30 \mathrm{~min})$ \\
3 & Accepts the massage half the time $(=1: 30 \mathrm{~min})$ \\
4 & Accepts the massage more than half the time $(>1: 30 \mathrm{~min}$ and $<3$ min $)$ \\
\hline
\end{tabular}

Ciência Rural, v.50, n.9, 2020. 
Table 2 - Goat behaviors observed during the massage protocols.

\begin{tabular}{|c|c|}
\hline Behavior parameters & - \\
\hline Trough interaction & $\begin{array}{l}\text { The goat approaches the trough puts its head inside and removes it quickly or stays long periods } \\
\text { awaiting for food or eats the concentrate food }\end{array}$ \\
\hline Water interaction & The goats drinks water from the automatic drinker or approaches the drinker and lick or bit it ${ }^{\mathrm{a}}$. \\
\hline Grooming & $\begin{array}{l}\text { The goat uses its teeth, horns or hind limbs to scratch itself or rubs any of its body parts in a } \\
\text { wooden column }{ }^{\mathrm{a}, \mathrm{b}} \text {. }\end{array}$ \\
\hline Lie down & The goats lay alone or close to each other, being sleepy or idle or attentive $\mathrm{e}^{\mathrm{a}}$. \\
\hline Exploratory behavior & $\begin{array}{c}\text { The animal directs its head toward the floor or fence touching or not its snout as if looking for } \\
\text { something }\end{array}$ \\
\hline Standing & $\begin{array}{l}\text { The animal stands still in normal or bipedal position, without any movement, staring the } \\
\text { environment outside the pen or other goats }{ }^{\mathrm{a}, \mathrm{c}} \text {. }\end{array}$ \\
\hline Ruminating lying down & The goat lies down and ruminates ${ }^{c}$ \\
\hline Ruminating when standing & The goat stands still and ruminates ${ }^{\mathrm{c}}$. \\
\hline Vocalizations & Vocal signals including snorts, bleats, and sneezes ${ }^{\mathrm{b}}$ \\
\hline Excretion behaviors & The goat urines and defecates ${ }^{\mathrm{b}}$. \\
\hline Affiliative behaviors & $\begin{array}{c}\text { Social positive behaviors as grooming (gently nibble other goat), sniffing, licking the base of the } \\
\text { udder, and resting in pairs }{ }^{\mathrm{a}, \mathrm{b}} \text {. }\end{array}$ \\
\hline Play between goats & $\begin{array}{l}\text { The animals approach each other and clashing their horns without aggressiveness; scrubs their } \\
\text { noses on their peers neck with an up and down movement }{ }^{\mathrm{a}} \text {. }\end{array}$ \\
\hline Agonistic behaviors & $\begin{array}{l}\text { Contact aggressive behaviors as biting, bumping, clash of the heads or horns in normal or bipedal } \\
\text { position, displacements or without contact as threat displays, chases, escapes }{ }^{\mathrm{a}, \mathrm{b}} \text {. }\end{array}$ \\
\hline Interact with the masseur & $\begin{array}{l}\text { The animals approach the masseur and clashing their horns without aggressiveness; sniffs or } \\
\text { scrubs their noses on the masseur; interacted aggressively or positively }\end{array}$ \\
\hline Vocalizations to the masseur & Vocal signals directed to the masseur \\
\hline Standing attentive to the masseur & The animal stands still in normal position, without any movement, staring the masseur \\
\hline
\end{tabular}

${ }^{a}$ Adapted score (SILVA et al., 2013).

${ }^{\mathrm{b}}$ Adapted score (MIRANDA-DE LA LAMA \& MATTIELLO, 2010).

${ }^{\mathrm{c}}$ Adapted score (PAULO \& LOPES, 2014).

the individual massage, if the goat's body was not visible, behaviors would not be accounted for. The P1 goats were filmed for $3 \mathrm{~h}, \mathrm{P} 2$ goats for $3 \mathrm{~h} 20$ minutes and each goat individually for $5 \mathrm{~h}$. The P1 goats had visible time on camera for $1 \mathrm{~h}: 35 \mathrm{~min}$; P2 goats for $3 \mathrm{~h}: 15 \mathrm{~min}$; $\mathrm{G} 1$ for $4 \mathrm{~h}: 30 \mathrm{~min}$; $\mathrm{G} 2$ for $3 \mathrm{~h}: 25$ min; G3 for 4:59 h; G4 for $4 \mathrm{~h}: 51 \mathrm{~min}$; G5 for $4 \mathrm{~h}: 50$ $\mathrm{min}$. At the end of each day, videos were stored in a computer for later analysis.

\section{Latency to the first contact the masseur}

On the first (D3) and last days (D14), the Latency to the First Contact Test (LFCT) was applied to GM and adapted to IM, evaluating only one goat (AWIN GOAT, 2015). The LFCT evaluates the time a group of goats takes to interact (smell, touch) with an unknown person within five minutes (300 s).

\section{Blood sampling and analysis}

Blood samples $(4 \mathrm{~mL})$ were collected from the jugular vein on D0 and D14 and stored in a refrigerated transport carton. An aliquot was used to prepare blood smears for differential white blood cells (WBC) count and the blood was centrifuged for $10 \mathrm{~min}$ at $6000 \mathrm{~g}$ to obtain serum, and stored at $-20^{\circ} \mathrm{C}$ until further analysis.

Blood smears were stained with DiffQuick stain and cells counted and classified as lymphocytes, monocytes, eosinophils, neutrophils or basophils. The ratio between neutrophils and lymphocytes was measured from each differential WBC in order to obtain N:L ratio. Quantification of serum malondialdehyde (MDA) was performed according to (BEZERRA et al., 2019) and expressed in serum as nmol/mL (DRAPER \& HADLEY, 1990).

\section{Statistical analysis}

Hematological and serum MDA values from day 0 and day 14 were compared through the paired non-parametric Wilcoxon signed-rank test. Individual comparisons of parameters related to behavior observations, latency to the first contact test, massage 
application and the influence of feeding schedule on massage score were performed through the nonparametric Kruskall-Wallis rank test. Comparison between pens was performed through the Wilcoxon signed-rank test. A confidence level of $95 \%$ was used to consider test results statistically significant.

\section{RESULTS AND DISCUSSION}

\section{Parameters related to massage application}

Mean $( \pm$ SEM) of massage score in the goats in GM and IM during the ten days are shown in figure 2 . There was no significant difference $(\mathrm{P}>0.05)$ observed. The G2 did not allow the touch on any day.

P1 goats only accepted touch from day 4 (Figure 2), indicating less interest or shyness regarding of the masseur. Stroking massage aims to promote relaxation (CORTI, 2014), but it is possible that animals within a group cannot easily reach this state due to factors such as dominance in the form of agonistic behaviors between goats (MIRANDA-DE LA LAMA\& MATTIELLO, 2010). Also conflicts for resources aiming to reduce individual freedom occurs between goats (MIRANDA-DE LA LAMA \& MATTIELLO, 2010), and some P1 goats attacked others during contact with the masseur.

Positive behaviors were observed after six days with P1 goats and seven days with P2 goats. Smelling and licking the masseur, bowing the head, nibbling the masseur, rubbing the head on the masseur, lying down and placing head on masseur's lap were noticed. Neutral behaviors were recognized after seven days in both groups: touching the timer, itching, urinating, ruminating standing, smelling the flour, vocalizing. Negative behaviors only occurred with P2 goats after four days, with goats biting and pulling the masseur's clothes. Negative behaviors during massage in animals may occur (MCBRIDE et al., 2004). To investigate the causes that motivated this behavior such as pain, touch sensitivity or anxiety (MCMILLAN et al., 2016), besides which animals presented this reaction in a group, is important to gather greater knowledge about each individual and their preferences.

It was observed in GM that the time of acceptance of massage might vary with the group

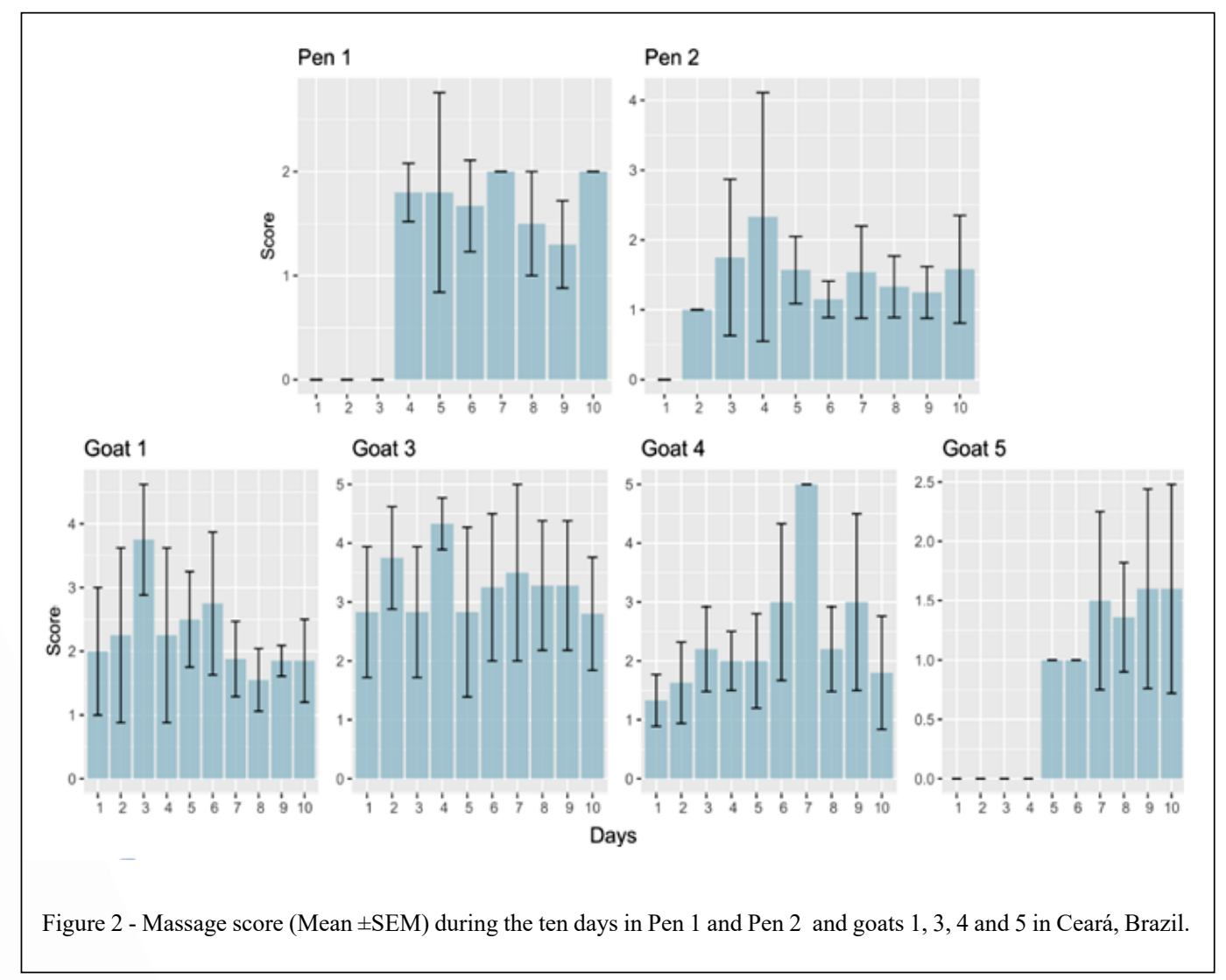

Ciência Rural, v.50, n.9, 2020. 
of animals to be massaged. Therefore, if GM is chosen, it is important to assess the occurrence of aggression between goats, which being observed, should be replaced by IM as a way to provide greater tranquility for the animal that is attacked to be able to relax and enjoy the massage.

As for individual results (Figure 2), it is likely that the application of massage in G1 generated a habituating effect to the procedure; which although, pleasant (presence of positive behaviors and absence of agonistic behaviors) did not stimulate the request for prolonged contact. The G3 and G4 (lied down with her legs straight close to the masseur) showed higher interest for the massage. The G5 required five days to allow touch and massage. In humans, touch is considered a tool capable of communicating positive feelings such as love and gratitude (HERTENSTEIN et al., 2006) and generating feelings in the recipient such as trust (GALLACE \& SPENCE, 2010). Goats that allowed contact for extended periods may have a higher degree of confidence in humans, which may be related to previous positive management experiences (WAIBLINGER et al., 2006). However, the existence of animals that take time to accept touch and massage (G5), as well as animals that do not accept it (G2), suggested that previous interactions with humans may possibly have been negative to these animals. In this case, a good HAR may be obtained with effective massage for a longertime period. Positive physical contact may alter relationship between humans and goats (JACKSON \& HACKETT, 2007), but some animals may take longer than others .

Positive behaviors were observed in G1, G3 and G4 from D1, and occurred for eight, nine and 10 days, respectively; G5 showed positive behaviors from the seventh day, for four days. Among the positive behaviors, there were smelling the masseur, nibbling the masseur's hand, licking the masseur and leaning the head on the fence, gently pulling the masseur's clothes, sniffing, lowering the head until she almost touched the floor, rubbing the underside of the head on the masseur's arm, flick the tail quickly, laying the head in the lap of the masseur and stretch the limbs. It was observed with IM that the goats that accepted the massage showed positive behaviors directed to the masseur from the first day of contact. Demonstration of affiliative behaviors, such as licking and sniffing (MIRANDA-DE LA LAMA \& MATTIELLO, 2010), towards the masseur during massage possibly indicates pleasure in receiving this interaction. Grooming and rubbing behaviors on the masseur have also been observed in massaged horses especially in withers and mild-neck, associated with a low heart rate and characterized as increased relaxation and a calm state (MCBRIDE et al., 2004). In this study, goats seemed to like to be touched in the facial region, because they stimulated contact with the masseur's hands. There may be differences between species and between individuals; therefore, it is important to note which area is best for touch.

The G1 and G3 had neutral behaviors from day one, and showed them for 10 days; G4, from day two, and showed them for nine days; G5 from day seven showed them for four days. Among neutral behaviors, there were smelling the ground, the fences and the wall, vocalizing, ruminating lying down and standing, scratching, smelling the timer, sniffing the ground and the fences, urinating and yawning. Scratching was a predominant behavior observed in goats in the present study. Also known as autogrooming, this behavior is often cited related to the animal's body hygiene, as a way to prevent tick infestation (AGUDELO; QUADROS; FILHO, 2013). At certain times, it was possible to observe the presence of mosquitoes in the pen, another aggravating factor for scratching. However, the behavior may also be related to psychosomatic factors as anxiety or stress (TEY; WALLENGREN; YOSIPOVITCH, 2013), generated by the possible waiting for food or being in a situation that indicates novelty. Therefore, observing the occurrence of this behavior during massage will be important in future studies.

Only G4 and G5 showed negative behaviors on days two and five, eight and ten, respectively. Among the negative behaviors, there were pushing the masseur's arm and hands with the head/horns, pulling hard on the masseur's clothing and biting the masseur. Occurrence of some of these behaviors raised the hypothesis that the presence of the masseur could be associated with frustration related to an association human-feeding period that culminates in aggression towards the masseur (NATARAJAN \& CARAMASCHI, 2010).

Among factors that may have influenced the acceptance of massage during the ten days, the feeding schedule was considered one of the most important with probable impacts on the acceptance of massage (Figure 3).

Despite attempts to apply massage at similar periods on the feeding schedule for all animals this was not possible due to delays or anticipations of this management. These differences may have been one of the causes why feeding schedule had no significant impact $(\mathrm{P}<0.05)$ on the mean $( \pm \mathrm{SEM})$ of massage score on goats individually. However, in most animals, with the exception of G1, scores were 


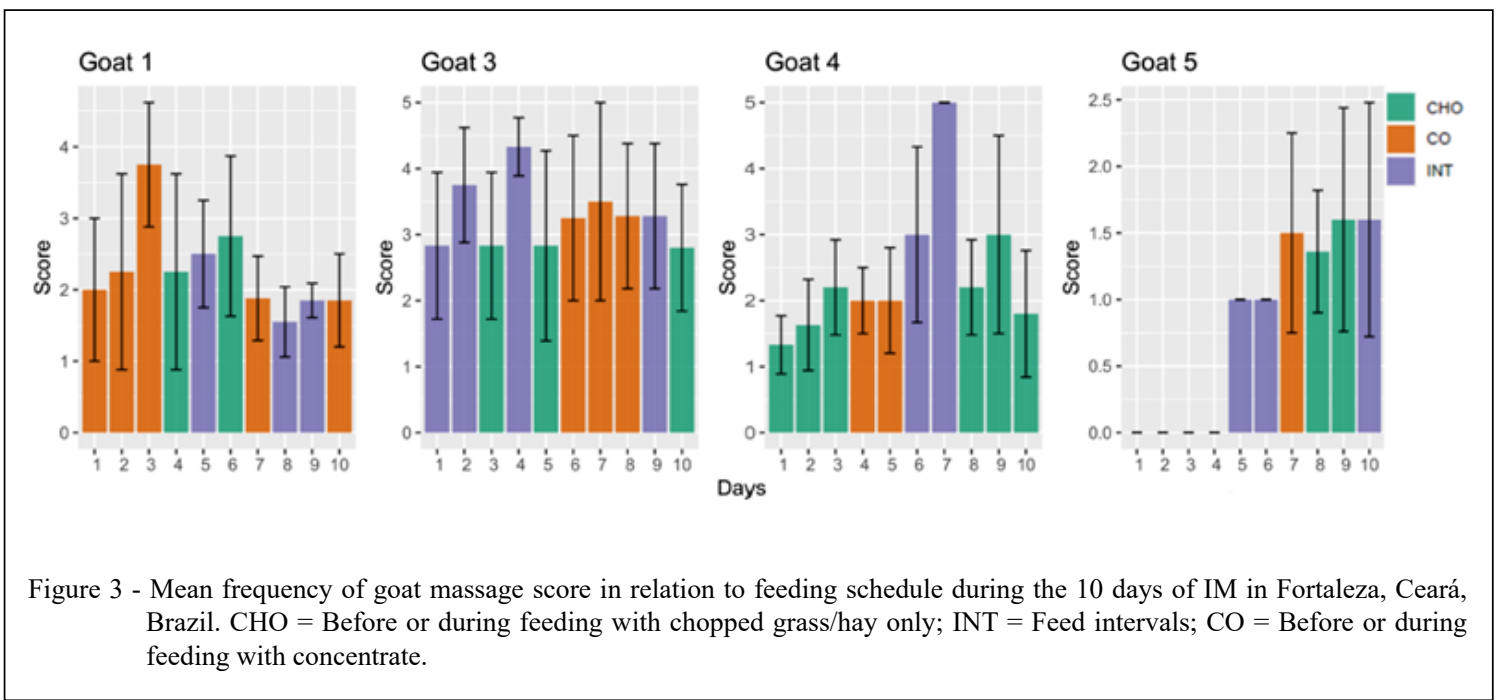

higher in the interval between feedings (Figure 3) probably due to physiological satiety.

Human-animal interaction can occur only during feeding time,leading these animals to associate the presence of humans with food as reward (WAIBLINGER et al., 2006). However, even if goats are able to differentiate stock people from other people, responsible for sanitary management and even surgical procedures, through an association of classical conditioning (WAIBLINGER et al., 2006), the authors proposed that massage should be performed during interval between feedings.

The authors observed that individually applied massage also allows the identification of each goat's preferences regarding the area of touch in addition to the different behavioral reactions. Therefore, massage application allows each goat to be individualized. This leads to the hypothesis that the person giving the massage forms a new perception of these animals, noting sentience, and thus treating them more positively. Future studies that observe the application of massage by stock people and the consequent treatment of goats should be performed.

\section{Others behaviors during massage}

Figure 4 shows the most prevalent behavioral variables. Among the observed behaviors, there was a significant difference $(\mathrm{P}<0.05)$ regarding trough interaction and standing for $\mathrm{B} 2 \mathrm{~W} 1$ versus B2W2 (Figure 4). Greater interactions with the drinker in the first week may be related to the hottest hours at the time of evaluation (ARAÚJO et al., 2010); curiosity in the new environment,and anxiety- like behavior generated by the new situation with masseur (psychogenic stressor), which may be caused by physiological changes in endocrine and autonomic nervous system that promoted hypernatremia (physical stress), leading to the desire to drink water and the behavior to seek water (KRAUSE et al., 2011). It stand decreased in the second week probably due to continuous contact that promoted a habituation to the new environment (WAIBLINGER et al., 2006) and the masseur.

\section{Latency to the first contact test}

On D3, each goat and both pens showed the maximum result for LFCT (300 s). On D14, results were G1: $81 \mathrm{~s} ; \mathrm{G} 2: 300 \mathrm{~s} ; \mathrm{G} 3: 250 \mathrm{~s} ; \mathrm{G} 4$ : 300 s; G5: 300 s; P1: 36 s; P2: 122 s. There was no statistical difference $(\mathrm{P}>0.05)$ between goats and pens. The massage period applied in this study (ten days) was not sufficient to generate voluntary approach of goats to the masseur. JACKSON \& HACKETT (2007) reported that goats with smooth and daily forced contact during 24 days presented a shorter approach time due to a habituation to human presence. Therefore, it is possible that massage forcibly applied to animals, and for a longer period (> 10 days), increases the desire for contact.

\section{Hematological and serum MDA values}

No statistical differences $(\mathrm{P}>0.05)$ were observed in these parameters, but there was a tendency to increase serum MDA in all goats $(\mathrm{P}=0.0625)$ (Figure 5). The WBC counts made from blood smears have been used as an alternative 


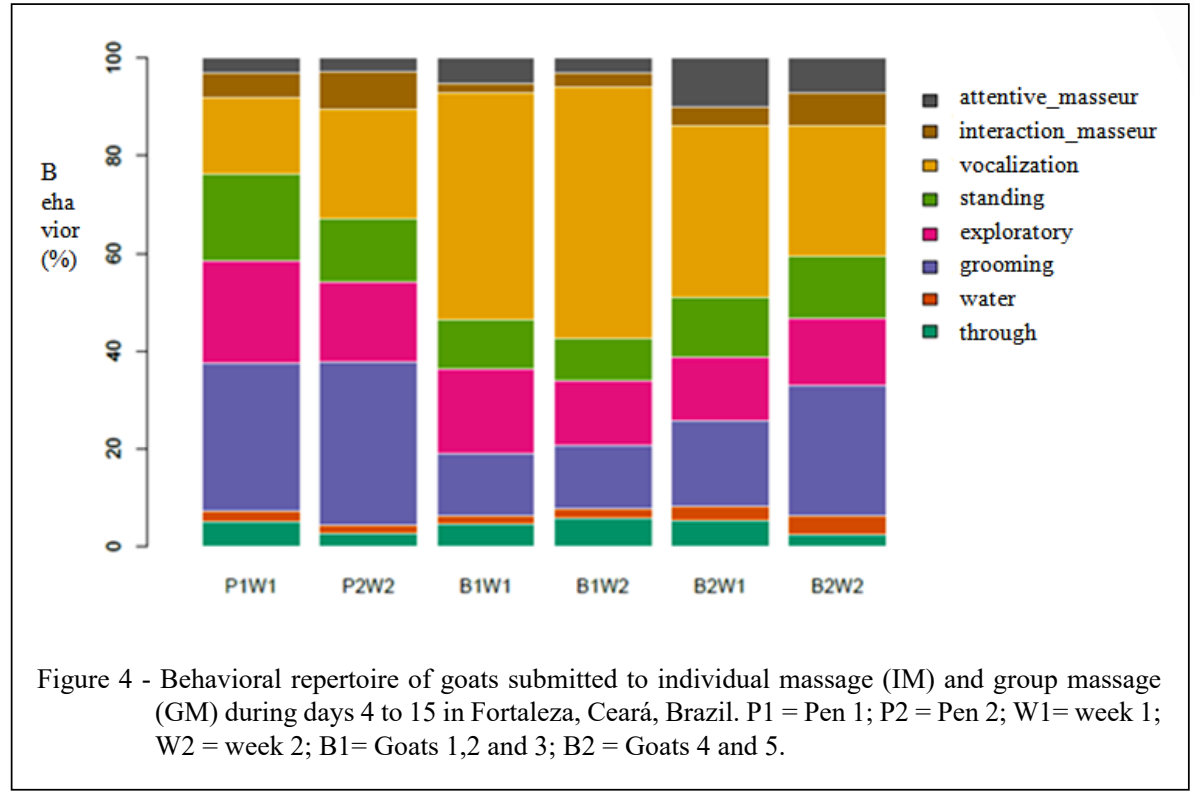

to hormones levels to measure stress in vertebrates animals due to low cost and rapid sampling (DAVIS et al., 2008). In this study, goats had a cell count at normal intervals (JONES \& ALLISON, 2007), with some presenting slight variations before and after massages; although, not as expressive. In stressful situations, there is a reduction in the amount of circulating lymphocytes in the blood as these cells migrate to tissues due to the release of glucocorticoids by adrenals (DHABHAR, 2002). In contrast, these hormones stimulate the release of neutrophils from the bone marrow into the blood, therefore the relation between neutrophil and lymphocytes (N:L ratio) is a reliable way to measure physiological stress (DAVIS; MANEY; MAERZ, 2008). Similarly, MDA is a product of lipid peroxidation, the free radical-

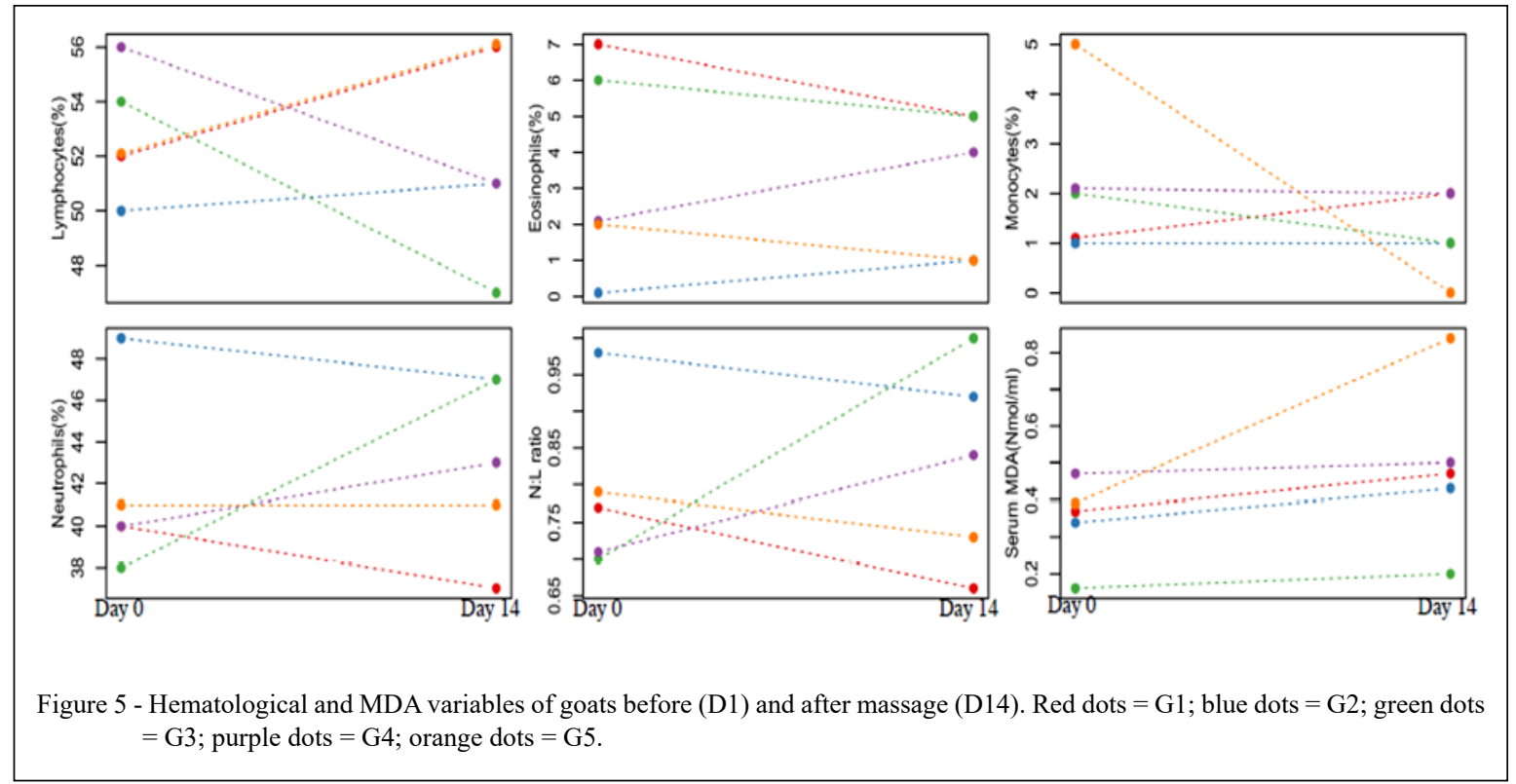

Ciência Rural, v.50, n.9, 2020. 
mediated chain of reactions that usually target biological membranes and promotes oxidative stress on cells when body's antioxidant system is unable to neutralize it (GROTTO et al., 2009). Therefore, serum MDA it is a blood component used to assess cellular oxidative stress. Absence of significant changes in hematological and serum MDA values indicated that contact with the masseur for ten days did not promote negative effects on the organism and homeostasis was maintained. In ruminants, studies on human-animal relationship and the analysis of serum MDA were not reported. However, a study that assessed serum MDA levels in dogs with or without a behavioral problem also showed no significant difference between both groups (SOLTANIAN; KHOSHNEGAH; HEIDARPOUR, 2016). These authors cited the need for a greater number of dogs in both groups $(n>16)$ to evaluate this difference.Results obtained in our study were opposite to those observed in humans undergoing massage, in which a significant reduction in serum MDA was observed compared to people who were not massaged (KARABULUT et al., 2013).

\section{Limitations of the study}

The positioning of the camera limited the observation area and consequently data was missing. This was a preliminary study, so the number of animals used was little. It is necessary to apply this protocol to a larger number of goats. In the case of massage applied to adult animals, it may be interesting to perform a habituation process with the masseur or provide food as a way of attracting animals to contact, especially in the case of very fearful animals like G2. Also, the effect of stroking technique on hormones' secretion in goats should be evaluated in future experiments. It has been noted that there is a need to reduce the space where the massage is applied as a way of facilitating contact with the goats. Finally, it is possible that heat in the hottest hours of the day, with heat spikes in the afternoon ( 2 to $3 \mathrm{pm}$ ) in Fortaleza, Ceará, Brazil (MOURA; ZANELLA; SALES, 2010), has been an itch elicitor on skin. Therefore, milder times of day should be considered for performing this procedure on animals.

\section{CONCLUSION}

This was a first attempt to establish a protocol of goat massage. Stroking massage promoted positive interactions between the masseur and the goats, especially when applied individually. Both massage protocols (GM and IM) did not promote alterations of blood parameters evaluated, indicating that it did not interfere in the homeostasis of the animals; being therefore, beneficial. The applied protocols also did not promote a reduction in the approach time from goat to the masseur in the latency of contact test during experimental period. Despite these results, the authors recommend exploring this technique as an alternative method to those existing in improving the relationship between humans and farm animals. Massage allows contact with the animal's body and may be a way of evaluating physical health through identified bruises, as well as a way to convey positive feelings to the massaged animal. Furthermore, aiming for better results, the authors suggested that new protocols should be tested in adult goats, including the increase in the number of animals evaluated and the application of massage forcibly and for a greater number of days, especially in the case of animals with only neutral or negative contact with stock people.

\section{ACKNOWLEDGEMENTS}

This study was supported in part by Coordenação de Aperfeiçoamento de Pessoal de Nível Superior (CAPES), Brasil, through a scholarship for the main author. We would also like to thank the Laboratorio de Imunologia e Bioquímica Animal (LIBA) for giving up the space to carry out part of the research, and Laboratório de Fisiologia e Controle da Reprodução (LFCR) for the assistence, both at Universidade Estadual do Ceará (UECE).

\section{BIOETHICS AND BIOSSECURITY COMMITTEE APPROVAL}

This study was approved by the Ethics Committee for the Use of Animals of State University of Ceará (00456440/2019).

\section{DECLARATION OF CONFLICT OF INTERESTS}

The authors declare that they have no conflicts of interest of personal, academic, political or financial interests relating to the publication.

\section{AUTHORS' CONTRIBUTIONS}

LOL, MJH, TRK, DCSNP conceived and designed experiments. VJFF provided the animals for the study. LOL performed the experiments and together with BMOB carried out the lab analyses. GP performed statistical analyses of experimental data and elaborated almost all the figures. All authors critically revised the manuscript and approved of the final version.

\section{REFERENCES}

AGUDELO, J. A. Betal. Scratching, cleaning and social bonding : grooming and their biological meaning in ruminants. Revista CES Medicina Veterinaria y Zootecnia, v.8, n.2, p.120-131, 
2013. Available from: <http://www.scielo.org.co/pdf/cmvz/v8n2/ v8n2a12.pdf>. Accessed: Jun. 20, 2019.

ALTMANN, J. Observational Study of Behavior: Sampling Methods. Behaviour, v.49, n.3, p.227-267, 1974. Available from: <http://www.uwyo.edu/animalcognition/altmann1974.pdf $>$. Accessed: Jun. 25, 2019.

ARAÚJO, G. G. L. DE et al. Water and small ruminant production. Revista Brasileira de Zootecnia, v.39, p.326-336, 2010. Available from: <http://www.scielo.br/pdf/rbz/v39sspe/36.pdf>. Accessed: Jul. 10, 2019.doi: 10.1590/S1516-35982010001300036.

AWIN GOAT. Animal Welfare Indicators for Goats. 2015. Available from: <https://air.unimi.it/retrieve/ handle/2434/269102/384790/AWINProtocolGoats.pdf $>$. Accessed: Jul. 5, 2019.

BEZERRA, B. M. O. et al. Evaluation of stress and performance of pigs during the nursery phase, using environmental enrichment techniques. Arquivo Brasileiro de Medicina Veterinaria e Zootecnia, v.71, n.1, p.281-290, 2019. Available from: <http:// www.scielo.br/pdf/abmvz/v71n1/0102-0935-abmvz-71-01-00281. pdf>. Accessed: Jul. 20, 2019. doi: 10.1590/1678-4162-10209.

BLOKHUIS, H. J. et al. The Welfare Quality ${ }^{\circledR}$ project and beyond: Safeguarding farm animal well-being. Acta Agriculturae Scandinavica, Section A - Animal Science, n.60, p.129-140 2010. Available from: <https://www.tandfonline.com/doi/abs/1 0.1080/09064702.2010.523480>. Accessed: Jun. 22, 2019. doi: $10.1080 / 09064702.2010 .523480$.

CELI, P. et al. Immunological, clinical, haematological and oxidative responses to long distance transportation in horses. Research in Veterinary Science, v.115, p.78-87, 2017. Available from: <https://www.sciencedirect.com/science/article/abs/pii/ S0034528817301042?via\%3Dihub>. Accessed: Jun. 24, 2019. doi: 10.1016/j.rvsc.2017.01.024.

CORTI, L. Massage Therapy for Dogs and Cats. Topics in Companion Animal Medicine, v.29, p.54-57, 2014. Available from: <https://www.sciencedirect.com/science/article/abs/pii/ S1938973614000038?via\%3Dihub>. Accessed: Jun. 24, 2019. doi: 10.1053/j.tcam.2014.02.001.

DAVIS, A. K. et al. The use of leukocyte profiles to measure stress in vertebrates : a review for ecologists. Functional Ecology, v.22, p.760-772, 2008. Available from: <https://besjournals.onlinelibrary. wiley.com/doi/epdf/10.1111/j.1365-2435.2008.01467.x>. Accessed: Jun. 28, 2019. doi: 10.1111/j.1365-2435.2008.01467.x.

DHABHAR, F. S. A Hassle a Day May Keep the Doctor Away: Stress and the Augmentation of Immune Function. Biology, Integrative and Comparative, v.42, p.556-564, 2002. Available from: $<$ https:// academic.oup.com/icb/article/42/3/556/723959>. Accessed: Mar. 30, 2020. doi: $10.1093 / \mathrm{icb} / 42.3 .556$.

DRAPER, H. H.; HADLEY, M. [43] Malondialdehyde Determination as Index of Lipid Peroxidation. Methods in Enzymology, v.186, p.421-431, 1990. Available from: <https:// www.sciencedirect.com/science/article/pii/00766879908613 5I?via\%3Dihub>. Accessed: Jul. 5, 2019. doi: 10.1016/00766879(90)86135-I.

FIELD, T. Touch and Massage in Early Child Development Johnson \& Johnson Pediatric Institute, L.L.C, 2004. 258p.
GALLACE, A.; SPENCE, C. The science of interpersonal touch: An overview. Neuroscience and Biobehavioral Reviews, v.34, p.246-259, 2010. Available from: <https://www.sciencedirect. com/science/article/abs/pii/S0149763408001723>. Accessed: Jul. 11, 2019. doi: 10.1016/j.neubiorev.2008.10.004.

GROTTO, D. et al. Importance of the lipid peroxidation biomarkers and methodological aspects for malondialdehyde quantification. Química Nova, v.32, n.1, p.169-174, 2009. Available from: $<$ http://www.scielo.br/pdf/qn/v32n1/v32n1a32.pdf $>$. Accessed: Jul. 1, 2019. doi: 10.1590/S0100-40422009000100032.

HERTENSTEIN, M. J. et al. Touch communicates distinct emotions. Emotion, v.6, n.3, p.528-533, 2006. Available from: $<$ https://psycnet.apa.org/record/2006-10747-018>. Accessed: Aug. 10, 2019. doi: 10.1037/1528-3542.6.3.528.

JACKSON, K. M. A.; HACKETT, D. A note: The effects of human handling on heart girth, behaviour and milk quality in dairy goats. Applied Animal Behaviour Science, v.108, n.3-4, p.332-336, 2007. Available from: <https://www.sciencedirect.com/science/ article/abs/pii/S0168159107000408>. Accessed: Aug. 7, 2019. doi: 10.1016/j.applanim.2007.01.011.

JONES, M. L.; ALLISON, R. W. Evaluation of the Ruminant Complete Blood Cell Count. Veterinary Clinics of North America - Food Animal Practice, v.23, n.3, p.377-402, 2007. Available from: $<$ https://www.ncbi.nlm.nih.gov/pubmed/17920454>. Accessed: Mar. 30, 2020. doi: 10.1016/j.cvfa.2007.07.002.

KARABULUT, A. B. et al. The effect of regular exercise and massage on oxidant and antioxidant parameters. Indian Journal of Physiology and Pharmacology, v.57, n.4, p.378383, 2013. Available from: <https://www.ncbi.nlm.nih.gov/ pubmed/24968576>. Accessed: Aug. 3, 2019.

KRAUSE, E. G. et al. Hydration State Controls Stress Responsiveness and Social Behavior. The Journal of Neuroscience, v.31, n.14, p.5470-5476, 2011. Available from: $<$ https://www.ncbi.nlm.nih.gov/pmc/articles/PMC3086063/ pdf/zns5470.pdf>. Accessed: Sep. 10, 2019. doi: 10.1523/ JNEUROSCI.6078-10.2011.

LÜRZEL, S. et al. Gentle interactions decrease the fear of humans in dairy heifers independently of early experience of stroking. Applied Animal Behaviour Science, v.178, p.16-22, 2016. Available from: <https://www.sciencedirect.com/science/article/ abs/pii/S0168159116300508>. Accessed: Sep. 15, 2019. doi: 10.1016/j.applanim.2016.02.012.

MARQUES, R. E. et al. Exploring the homeostatic and sensory roles of the immune system. Frontiers in Immunology, v.7, n.MAR, p.1-7, 2016. Available from: <https:/www.ncbi.nlm. nih.gov/pmc/articles/PMC4814584/pdf/fimmu-07-00125.pdf>. Accessed: Sep. 15, 2019. doi: 10.3389/fimmu.2016.00125.

MCBRIDE, S. D.; HEMMINGS, A.; ROBINSON, K. A Preliminary Study on the Effect of Massage. Journal of Equine Veterinary Science, v.24, n.2, p.76-81, 2004. Available from: $<$ https://www.ncbi.nlm.nih.gov/pmc/articles/PMC4814584/pdf/ fimmu-07-00125.pdf $>$. Accessed: Jun. 27, 2019. doi: 10.1016/j. jevs.2004.01.014.

MCMILLAN, F. D. et al. Behavioural characteristics of dogs removed from hoarding situations. Applied Animal Behaviour Science, v.178, p.69-79, 2016. Available from: <http://www. 
islandscholar.ca/islandora/object/ir:15771>. Accessed: Jul. 30, 2019. doi: 10.1016/j.applanim.2016.02.006.

MIRANDA-DE LA LAMA, G. C.; MATTIELlO, S. The importance of social behaviour for goat welfare in livestock farming. Small Ruminant Research, v.90, n.1-3, p.1-10, 2010. Available from: <https:/www.sciencedirect.com/science/article/ abs/pii/S0921448810000192>. Accessed: Jul. 30, 2019. doi: 10.1016/j.smallrumres.2010.01.006.

MOURA, M. DE O.; ZANELLA, M. E.; SALES, M. C. L. Conforto térmico em Fortaleza-Ce. Revista da ANPEGE, v.6, p.177-189, 2010. Available from: <http://ojs.ufgd.edu.br/index. php/anpege/article/view/6584/3584>. Accessed: Nov. 15, 2019. doi: 10.5418/RA2010.0606.0011.

NATARAJAN, D.; CARAMASCHI, D. Animal violence demystified. Frontiers in Behavioral Neuroscience, v.4, p.1-16, 2010. Available from: <https://www.frontiersin.org/ articles/10.3389/fnbeh.2010.00009/full>. Accessed: Oct. 20, 2019. doi: $10.3389 /$ fnbeh.2010.00009.

PAULO, J. L. DE A.; LOPES, F. DE A. Daily activity patterns of Saanen goats in the semi-arid northeast of Brazil. Revista Brasileira de Zootecnia, v.43, n.9, p.464 470, 2014. Available from: <http:/ www.scielo.br/pdf/rbz/v43n9/1516-3598-rbz-43-09-00464.pdf>. Accessed: Sep. 20, 2019. doi: 10.1590/S1516-35982014000900002.

ROBERTSON, J.; MEAD, A. Physical Therapy and Massage for the Dog. London: Manson Publishing Ltd, 2013. 224p.

SHARP, B. Feline physiotherapy and rehabilitation: 2. Clinical application. Journal of Feline Medicine and Surgery, v.14, p.622-632, 2012. Available from: <https://journals.sagepub.com/ doi/10.1177/1098612X12458210>. Accessed: Sep. 20, 2019. doi: $10.1177 / 1098612 X 12458210$.
SILVA, C. M. DA et al. Ethogram of three genetic groups of goats confined using monitoring video images. Revista de Etologia, v.12, p.1-11, 2013. Available from: <http://pepsic.bvsalud.org/ pdf/reto/v12n1-2/a01v12n1-2.pdf>. Accessed: Sep. 5, 2019.

SOLTANIAN, A.; KHOSHNEGAH, J.; HEIDARPOUR, M. Comparison of serum trace elements and antioxidant levels in terrier dogs with or without behavior problems. Applied Animal Behaviour Science, v.180, p.87-92, 2016. Available from: $\quad<$ https://www.sciencedirect.com/science/article/abs/pii/ S0168159116301010?via\%3Dihub>. Accessed: Mar. 30, 2020. doi: 10.1016/j.applanim.2016.04.012.

SUTTON, A.; WHITLOCK, D. Massage. In: MILLIS, D.; LEVINE, D. (Eds.).Canine Rehabilitation and Physical Therapy. 2.ed. Philadelphia: Elsevier Sauders, 2013. p.464-483.

TEY, H. L.; WALLENGREN, J.; YOSIPOVITCH, G. Psychosomatic factors in pruritus. Clinics in Dermatology, v.31, n.1, p.31-40, 2013. Available from: $<$ https://www.sciencedirect.com/science/ article/pii/S0738081X11003300?via\%3Dihub $>$. Accessed: Sep. 20, 2019. doi: 10.1016/j.clindermatol.2011.11.004.

WAIBLINGER, S. et al. Assessing the human-animal relationship in farmed species: A critical review. Applied Animal Behaviour Science, v.101, p.185-242, 2006. Available from: <https://www.sciencedirect.com/science/article/pii/ S0168159106000475>. Accessed: Nov. 1, 2019. doi: 10.1016/j. applanim.2006.02.001.

ZULKIFLI, I. Review of human-animal interactions and their impact on animal productivity and welfare. Journal of Animal Science and Biotechnology, v.4, p.1-7, 2013. Available from: <https://jasbsci.biomedcentral.com/ articles/10.1186/2049-1891-4-25>. Accessed: Jun. 25, 2019. doi: 10.1186/2049-1891-4-25. 